\title{
Obstacles of Internationalized Medicine
}

\section{Athanasios K Petridis*}

Associate Professor, Department of Neurosurgery, Wedau Kliniken and Sana Konzern Duisburg, Germany

Nowadays there is a tendency of patient transfer all over the world. Patients from different countries are treated in Europe and the US. In most cases these patients are war victims with complex wounds. In Germany we treated a number of patients from the Libyan war. It is a very positive characteristic of our modern society to break state limits and borders in order to heal patients. Medical doctors are the first to show that in a modern human society there should not be any limits in the provision of care.

However, there are some obstacles complicating the care of such patients. The bacterial spectrum of infected wounds is different that the one we are dealing in our everyday routine. Wounds are infected with multiresistant bacteria and the antibiotics, which are routinely used are not effective in a significant number of cases. This led to infections of other intensive care patients even when the preventions where followed strictly. The patients from such countries are placed in carrantine in order to avoid infecting other patients with multiresistant bacterial strains. We faced following problems: infestation of the ICU and need to evacuate the ICU for disinfection. The ICU was not available for 3 days. Antibiotics, which are extraordinary expensive have to be used destabilising the economic status of our department.

In conclusion we would like to stress out the problems coming towards us in the future. Internationalized medicine should stay and always be our aim to care for human beings in need all over the world, overseeing economical facts. Economy is not the doctors driving force. However, knowledge of problems like special carrantine methods, different antibiotic spectrum for multiresistant bacterial strains etc. would change our approach to a more effective one and could avoid problems like putting a whole ICU out of order for disinfection.
*Corresponding author: Athanasios K Petridis, Department of Neurosurgery, Wedau Kliniken and Sana Konzern DuisburgZu den Rehwiesen 9, Duisburg 47055 Germany, Tel: +49-203-733-2425; Fax: +49-203-7330; E-mail: opticdisc@aol.com

Received August 09, 2013; Accepted August 10, 2013; Published August 12, 2013

Citation: Petridis AK (2013) Obstacles of Internationalized Medicine. J Neurol Disord 1: e105. doi:10.4172/2329-6895.1000e105

Copyright: ( $) 2013$ Petridis AK. This is an open-access article distributed under the terms of the Creative Commons Attribution License, which permits unrestricted use, distribution, and reproduction in any medium, provided the original author and source are credited. 